\title{
Experiences of Teachers and Learners in the Teaching and Learning of Physical Education in Selected Schools in Monze, Zambia
}

\author{
Thomas Mwale, John Mwitumwa Matakala*, Chimfwembe Mwenya-Mwale, Chanda \\ Chishimba, Mubiana Macwang'i Anne Namakando-Phiri \\ Department of Physical Education, University of Zambia, Lusaka, Zambia
}

*Corresponding Author: John Mwitumwa Matakala, Department of Physical Education, University of Zambia, Lusaka, Zambia

\begin{abstract}
This study was aimed at exploring and understanding the lived experiences of the teachers and learners of physical education in the learning and teaching. In order to understand the experiences, the study made use of a qualitative inquiry grounded in existential phenomenology.
\end{abstract}

Purposive Sampling was used to come up with the desired sample size of and the resultant data that were collected. Data collection was achieved by use of in-depth face to face and focus group interviews. The data were analyzed using content analysis in order to transcribe the bulk data into themes and sub themes.

The findings were categorized in line with the objectives of the study which where (a)Benefits of physical education (b) teacher's perceptions on the teaching and (c) Learners perceptions on the learning.

The findings of the study on the benefits using in - depth interviews show that the subject maintains fitness, enhances skills in the various games, ensures promotion for teachers and improve their curriculum vitae.

The findings further show that it encourages excursions.

The findings on the teacher perceptions on teaching show lack of instructional materials in terms of text books, lack of good playing fields and materials, lack of infrastructure and lack of professional enhancement at the university due to the subject being graded under primary qualification.

The findings of the learner perceptions on the learning show lack of materials in form of text books. Furthermore, the findings show that the materials to use at the grounds such as lime are improvised and also the nets for the goal posts are improvised. It was further established that because of lower theory and practice as a result of unbalanced allocation of periods the children failed the subject during mock examinations. Arising from the findings also show that the girl child is stigmatized by parents for participation in the games at home that they will not bear children in future.

These findings show that if the problem is not checked it is likely to affect the 50-50 participation in terms of learning and equal pass rate during the examinations if not addressed.

It is against this background that in order to improve the situation a number of recommendations have been put forward for consideration by the Ministry of Education (MOE) and individual school managers for use of initiative to ameliorate the situation.

Keywords: Teachers, Learners, Physical Education and Phenomenological Perspective.

\section{INTRODUCTION}

\subsection{Background to the Study}

Worldwide theoretical evidence has shown a source of concern with regard to the negative attitude shown to physical education both in tertiary and secondary education by administrators and policy makers. It has received marginalization in comparison to other subjects especially in the countries in the southern part of the equator in terms of deficiencies in curriculum time allocation, administrative care and financial support. This was revealed at the world Berlin Physical education summit which confirmed the said identified problem attended by many countries which included our country. UNESCO (2005). 
Zambia's geographical location is found in the aforementioned latitudinal position hence the need for empirical evidence to ascertain whether or not the assertion is a true reflection.

It must be observed that be noted that the teacher and the learner are the most affected.

Many concerned scholars and research studies reacted to the concerns of the united nations from the identified research problem so as to collect empirical evidence with a view of solving the problem at global level in world by the following scholars, Ross and Hargreaves; (1995), and Storthart, (1997), Nhamo and Muswazi, (2013) and Muswazi (2014), Kapembwa; 2015, Sitima; 2015, Mwashingwele; 2015 and Shimishi 2015.

While the above scholars triedto solve the above problem, it appears none of them looked at the phenomenological perspective of both the teachers and the learners at the junior secondary level based on the teaching and learning process.

The afore mentioned studies looked at the implementation of physical education in schools. While the afore mentioned studies may have tackled the concerns of the present study they either considered an element each which was for the teacher or learner a knowledge gap that this study intends to address by combining both.

The motivation behind this study is that if the negative attitude towards the teaching and learning of physical education is not put on check it is likely to lead to the extinction of the subject therefore it is worth addressing hence it calls for an investigation.

\subsection{Statement of the Problem}

Experiences of Teachers and Learners in The Teaching and Learning of Physical Education in Selected Schools in Monze, Zambia has not been done This is a compelling knowledge gap.

\subsection{General Objective}

To explore and understand the lived experiences faced in the teaching and learning of physical education by the actual stakeholders in selected schools of Monze.

\subsection{Specific Objectives To}

i. ascertain the benefits of teaching physical education in primary schools

ii. Establish the teacher's perception towards teaching physical education in primary schools.

iii. understand the problems faced by learners in the teaching of physical education in primary schools

\subsection{Research Questions}

iv. What are the benefits of teaching physical education in primary schools?

v. What is the teacher's perception towards teaching physical education in primary schools?

vi. What are the problems faced by learners in the teaching of physical education in primary schools?

\subsection{Significance of the Study}

This study is ground breaking because it will not only concentrate on separately looking at the teachers and learners with regard to the teaching and learning of physical education. The results and recommendations will further be forwarded to policy makers for practical implementation.

This study would provide policy makers, the Ministry of General Education with ideas about competencies relevant to the teaching of physical education in the primary schools and may also form the basis for improvement in the subject

It is also hoped that it will act as a stepping stone for further research apart from adding knowledge to the discipline of physical education at the University of Zambia.

\subsection{Ethical Consideration}

Ethical clearance was obtained from the ethics Committee of the University of Zambia. Thereafter, dual permission was sought involving the District Education Board Secretary (DEBS) in Monze Southern Province authorities and the actual participants. 


\subsection{Definition of Terms}

- Primary school: school running from grades ones up to nine of which this study focusses on the grade eight and nine classes.

- Physical education: the part of the school curriculum that aims to educate young people through physical activity. An important aim is to promote the adoption of a physically active lifestyle that persists through adulthood".

\subsection{Purpose Statement}

The purpose of this Existential Phenomenological inquiry was to uncover the meaning, articulated 'essences of thelived experiences faced in the teaching and learning of physical education by the actual stakeholders in selected schools and ideas of the participants from the insider's view called the 'emic' perspective Holloway and Wheeler (1996). It further assisted in the articulation and amplification of the experiences of Physical Education teachers and learners.

Methods of inquiry included a phenomenological reflection on data elicited by existential investigation of soldiers experiences and investigation of the phenomenon in the creative arts Creswell (2009).

\section{Methodology}

A qualitative research approach was used grounded in the philosophy of Interpretivism in order to understand the teacher and learner experiences and interpretations of sexual harassment among soldiers. The research design that was used was the Existential phenomenology to get down to the Teacher and learner Phenomenological Perceptions as well as allowing the researcher to bracketing his ideas by only getting views of participants Egaden (2012).

The study was conducted in the Southern part of Zambia in particular Monze District from four selected schools from leaners and teacher's experiences on the teaching and learning experiences. Judgmental were used to come up with the desired sample size of 32 participants of which 16 were teachers and 16 were learners shared equally from the four selected schools using an availed sampling frame or lists by the relevant authorities.

The resultant data were collected through the in-depth interview guides from the teachers while focus group discussion guides were used to the female and male learners. Data collection procedure began with the pretest, prescribed interview process and sequential strategy actual data collection.

- Pretest: Before the actual data collection, the interview guides and focus group discussion guides were subjected to prior collection so as to standardize the research instruments so that they are able to collect the desired information.

- Interview process: The participants were first greeted by the researcher. They were later told the purpose of the study and consent was gotten from them before the inquiry. They were also assured of confidentiality and that they had a right to pull out at any time they felt uncomfortable as it was there right before commencement of the interview.

- Sequential transformative strategy: Was used to collect the data because the objectives were followed chronologically and were all qualitative by nature Creswell (2009).

The findings were thermalized chronologically in line with the first objective which was on the nature of sexual harassment, coping strategies and the regulatory measures.

The data were analyzed by the use of the phenomenological data analysis by reducing the large amounts of data by transcribing each script in order to come up with the themes and sub themes of the inquiry.

Furthermore, issues of trustworthiness were achieved through Guba's four trustworthy strategy of credibility, dependability, transferability and Confirmability. It falls under the volunteristic axiology which looks at ethics and aesthetics which looks at the value of the study academically. Guba and Lincoln (1994).

- Credibility: Was ensured by choosing of the correct research design or plan which was the existential phenomenology hence the data is correct and is acceptable academically. 
- Dependability: Was done through standardizing the research instruments so that they get the desired information hence the data is correct and is acceptable academically.

- Confirmability: Was done by ensuring the phenomenological reduction or 'epoche' or bracketing of pre conceived ideas through listening and taking the information as it comes.

- Transferability: Was done through the afore mentioned in that the study has the capacity of being contextualized with other studies so as to come up with similarities which can lead to identification of gaps by other studies.

\section{RESUltS \& DisCUSSION}

\subsection{What are the Benefits of Teaching Physical Education in Primary Schools?}

\section{Contextualised Similarities with Other Empirical Studies}

\begin{tabular}{|c|c|}
\hline $\begin{array}{l}\text { Empirical Findings on Benefits of teaching } \\
\text { Physical education from Literature Review }\end{array}$ & $\begin{array}{l}\text { Research Findings on the Benefits of teaching } \\
\text { Physical education for this Study }\end{array}$ \\
\hline $\begin{array}{l}\text { - The findings from empirical literature show } \\
\text { the following benefits of the teaching of } \\
\text { Physical Education; } \\
\text { - Global Perspective. } \\
\text {-Maintains good health to the body Faber E'tal } \\
\text { (2007). } \\
\text { Regional Perspective } \\
\text {-Physical Education offered at the } \\
\text { University and Colleges for academic } \\
\text { Enhancement by teachers Muswazi and } \\
\text { Nhamo (2013). } \\
\text { Local Perspective } \\
\text {-The findings show that it improves ball } \\
\text { Game skills in both learners and teachers } \\
\text { Hence outdoor games are liked by both } \\
\text { The stakeholders Kapembwa (2015). }\end{array}$ & $\begin{array}{l}\text { - The findings of this study are in agreement with } \\
\text { the other studies on the benefits of teaching } \\
\text { physical education. } \\
\text { The findings of this study are similar because it } \\
\text { appears there is universality in the way it is done } \\
\text { at global level. } \\
\text { - Whether it is at global, regional and local } \\
\text { Level mantaince of good healthy and skill } \\
\text { improvement will be the same if practice is } \\
\text { enhanced. }\end{array}$ \\
\hline
\end{tabular}

Source: Field Data (2017) and Empirical Literature

This is what the participants had to say when asked what the benefits of teaching of physical education are;

A male physical education teacher (a) from HamangabaSchool (Pseudo Name) had this to say when asked on what were the benefits of the teaching and learning of Physical Education were:

"Sir meaning the researcher in my teaching and learning of physical education I

Found it very interesting and beneficial because I did not expect to be seconded

To teach physical education at secondary school It also maintains good

Good health for me and my learner."

\section{Contextualised Disimilarities with Other Empirical Studies}

This study came up with the finding that one of the benefits of teaching physical education is that improves the curriculum vitae of the teacher in that they produce learners that participate in world events such as the Olympic youth games.

From an interaction with literature it appears none of the studies came up with this finding hence it is new knowledge.

The difference in this finding with other studies might be attributed to the consistence a type of training given to those learners and sometimes it may be inborn.

This is what the participants had to say when asked what the benefits of teaching of physical education are;

A male physical education teacher (c) from Hamangaba School (Pseudo Name) had this to say when asked on what benefits of Physical Education are commented that: 
"Sir meaning the researcher recently one of the pupil I was teaching was engaged Sporting activities at national level which is important for my curriculum vitae...."

\subsection{What is the Teacher's Perception towards Teaching Physical Education in Primary Schools?}

\section{Contextualised Similarities with Other Empirical Studies}

\begin{tabular}{|l|l|}
\hline $\begin{array}{l}\text { Empirical Findings on teacher perception of } \\
\text { teaching Physical education in primary school } \\
\text { from Literature Review }\end{array}$ & $\begin{array}{l}\text { Research Findings on the teacher perception of } \\
\text { teaching Physical education in primary schools for } \\
\text { this Study }\end{array}$ \\
\hline $\begin{array}{l}\text { The findings from empirical literature show } \\
\text { the following teacher perceptions of the } \\
\text { teaching of Physical Education; }\end{array}$ & $\begin{array}{l}\text { The findings of this study are in agreement with } \\
\text { the other studies on the teacher perceptions of } \\
\text { teaching physical education. }\end{array}$ \\
$\begin{array}{l}\text { Global Perspective. } \\
\text {-Lack of infrastructure such as a swimming pool in } \\
\text { New Zealand Storthart (1997). }\end{array}$ & $\begin{array}{l}\text { The findings of this study are similar because it } \\
\text { appears there is universality in the availability of } \\
\text { resources which are scarce to come up with the } \\
\text { infrastructure and instructional materials at global } \\
\text { level. }\end{array}$ \\
$\begin{array}{l}\text {-Lack of instructional materials such as } \\
\text { Text books. }\end{array}$ & $\begin{array}{l}\text { However, for first world countries such as New } \\
\text { Zuswazi and Nhamo (2013). } \\
\text { of a suitable place to construct a swimming pool. }\end{array}$ \\
$\begin{array}{l}\text { Local Perspective } \\
\text {-The findings show that there was lack of } \\
\text { Cooperation from other teachers when it }\end{array}$ & \\
$\begin{array}{l}\text { Comes to time tabling of subjects } \\
\text { Sitima (2015). }\end{array}$ &
\end{tabular}

Source: Field Data (2017) and Empirical Literature

This is what the participants had to say when asked what the perceptions of teaching of physical education are;

A male physical education teacher (a) from Hansungule School (Pseudo Name) had this to say when asked on his perceptions in the teaching of Physical Education were:

"Sir meaning the researcher in my teaching of physical education I have seen

Challenges in terms of instructional materials such as text books. We only have

One which is being usedwhich happens to have errors on certain topics......

Presently it has issues which are in court with Abigale Tuchili having sued

The publishers for using her name.....

\section{Contextualised Disimilarities with Other Empirical Studies}

This study came up with the finding that one of the perceptions of teaching physical education is that there is lack of professional enhancement at the University of Zambia. This is because at the institution the subject is certificated under Bachelor of Primary Degree as it is not yet a department.

From an interaction with literature it appears none of the studies came up with this finding hence it is new knowledge.

The difference in this finding with other studies might be attributed to the differential policies in handling of the course because at the level of college it appears there is universality with others at global level.

A physical education teacher from Mbereshi School (Pseudo Names) had this to say when asked on what his perceptions were in the upgrading of at the university of Zambia in terms of certification of Physical Education commented that:

"Basa tonga word 'meaning sir to the researcher, Cikolo chipati chaluiyo mu ciisi cheesu Cha Zambia, tachibiti kabotu, nkambo batupa pepa yakuisya bana bamukotolo

Twamatalikilo in tonga meaning the university of Zambia is being unfair by giving as

A primary degree. 
Sir meaning the researcher this means as that are seconded might just be taken back to Primary level of teaching

\subsection{What is the Learner's Perception towards Learning of Physical Education in Primary Schools?}

\section{Contextualised Similarities with Other Empirical Studies}

\begin{tabular}{|c|c|}
\hline $\begin{array}{l}\text { Empirical Findings on learner perception of } \\
\text { learning Physical education in primary school } \\
\text { from Literature Review }\end{array}$ & $\begin{array}{l}\text { Research Findings on the learner perception of } \\
\text { learning Physical education in primary schools for } \\
\text { this Study }\end{array}$ \\
\hline $\begin{array}{l}\text { - The findings from empirical literature show } \\
\text { the following learner perceptions of the } \\
\text { learning of Physical Education; } \\
\text { Regional Perspective } \\
\text {-Lack of learning materials such as } \\
\text { Text books and jerseys. } \\
\text { Muswazi and Nhamo (2013). } \\
\text { Local Perspective } \\
\text {-The findings show no good learning } \\
\text { Infrastructure such as grounds and } \\
\text { Materials for grounds. } \\
\text { Sitima (2015). }\end{array}$ & $\begin{array}{l}\text { - The findings of this study are in agreement with } \\
\text { the other studies on the learner perceptions of } \\
\text { learning physical education. } \\
\text { - The findings of this study are similar because it } \\
\text { appears there is universality in the availability of } \\
\text { resources which are scarce to come up with the } \\
\text { infrastructure and instructional materials at global } \\
\text { level. }\end{array}$ \\
\hline
\end{tabular}

Source: Field Data (2017) and Empirical Literature

This is what the participants had to say when asked what the perceptions of teaching of physical education are;

Perceptions of the group of the learners on lack of nets for football goal posts

Participant ' $\mathrm{B}$ ' of Hamangaba [ii] had this to say when the researcher asked the group on their perceptions on the learning of physical education in terms of problems

'Sir 'meaning the researcher' thank you very much for giving me a chance to speak.

To begin with I would like to show my disappointment at the school authorities

Attitude toward physical education in terms of provision of materials for use during

Our practical's especially to availing as with nets to use for the goal posts.

Sir 'meaning the researcher' we have had to improvise at our school by coming with

Mealie meal sacks which are given to the girls doing home economics to knit for us....

Things are not ok I end here may be my friends can also say

Something."

Perceptions of the group of the learners on lack of nets for football goal posts

Participant ' $\mathrm{B}$ ' of Hamangaba [ii] had this to say when the researcher asked the group on their perceptions on the learning of physical education in terms of problems

"Thank very much for giving me a chance to speak. I believe you're to this district is

Going to solve some of our problems. Firstly, I want to agree with the previous speaker

With a tag marked Hamangaba school even though you have said I come up with me

Own view. When we are playing football other than the first concern we have problems

When the ball has gone outside the pitch.... due to know

Lime for marking the pitch.

However, we try to improvise by digging a straight line using a hoe

\section{Contextualised Disimilarities with Other Empirical Studies}

This study came up with the finding that one of the perceptions of learning physical education is that there are lower teaching periods for the subject hence they did not do well during the Mock Examinations. 
Furthermore, it was revealed that there was stigmatization of the girl child whenever they participated in physical education practical exercises such as athletics. This type of comments might affect the fifty-fifty participation required for equal participation of this subject at the same level with the boy child.

From an interaction with literature it appears none of the studies came up with these findings hence it is new knowledge.

The difference in this finding with other studies might be attributed to the differential policies in handling of the subject in terms of administration.

It is against this background when the girls group was asked this is what they had to say;

Perceptions of the group of the learners on lack of enough or fewer learning periods and performance.

Participant ' $\mathrm{B}$ ' of Hamangaba [ii] had this to say when the researcher asked the group on their perceptions on the learning of physical education in terms of problem.

"I want to state that our results were poor because physical education is allocated fewer

Learning periods and because of that I failed and most of my friends in this group will

Agree with me....

This will make all of us in this group do badly during the final examinations.......... ,"

Perceptions of the group of the learners on the learning problems or challenges.

Participant 'a' of Hamangaba [ii] had this to say when the researcher asked the group on their perceptions on the learning of physical education in terms of problem.

"Sir meaning the researcher I begin by thanking the previous speaker. Mine is an

Observation, one of the challenges as girls find in the society by our parents is that

They say bad words on us.....

They normally tell us that you will not bear children if you continue............."

\section{CONCLuSion}

The conclusion of the whole matter is that this study will avail information to the policy makers for policy implementation from the findings of the out lined research questions.

- What are the benefits of teaching physical education in primary schools?

- What is the teacher's perception towards teaching physical education in primary schools?

- What are the problems faced by learners in the teaching of physical education in primary schools?

The findings for research question one show that the benefits of the teaching and learning of physical education included among others the mantaince of fitness on both the teacher and the learner so as to avoid diseases. Additionally, it increases skill in the learners and it also adds value to the curriculum vitae for the teacher when a learner excels. The other benefit is that it leads to promotions such as being elevated to teach at a college of education.

The findings for the research question two show that there was lack of instructional materials for teaching such as books. Additionally, the other drawback was lack of infrastructural facilities to teach the children from. Furthermore, unbalanced allocation of learning periods with the subject receiving less.

The findings for the research question three show that there was lack of learning materials for use and lower theory and practice of the subject due to few contacts. The other finding was the stigmatization of the girl child by parents siting that it may result in the complication of not having children in future due to the strenuous exercises.

Owing to this conclusion there is a need of proposing of recommendations based on the researcher perspective to mitigate the problem so as to inform policy. 


\section{RECOMMENDATIONS}

In view of the important role that is attached to the subject of physical education in terms of promoting good healthy and skills there is a need for conceited efforts by stake holder such as the ministry of education to implement the proposed recommendations of this study. The findings of this study inform the ministry of education in Zambia to find lasting policy that should mitigate the teaching and learning of physical education improvement, that will not only better it here in Zambia but also other schools globally.

This should be done in the most effective and sufficient manner as suggested below by the researcher. Presented below are the proposed recommendations.

- The ministry of education (Moe) should come up with a deliberate policy to ensure allocation of periods is balanced in relation to other subjects. This can be achieved by coming up with an instruction at national level to all schools as a start point.

- The ministry of education (Moe) should go into a memorandum of understanding (Mou) with Non-Governmental Organizations (Ngos) that are ready to assist in the subject. This idea must also be encouraged at school level.

\section{RECOMMENDATIONS FOR FURTHER STUDIES}

It is recommended that that a future study must consider undertaking the development of a teacherlearner participatory conducive approach for learning and teaching of physical education through the use of social or emancipation action principles with the usage of the interprativist participatory approach and the interprativist emancipation phenomenology Egaden(2012).

This process must be considered for Doctoral Studies being an action research oriented process.

- Social Action: Is a two phased inquiry which begins by finding answers through participant experiences from prerequisite standardized research questions, after which the researcher develops an action agenda for change, which is used for establishing ways for conducive teaching and learning of physical education based on victim ideas under his guidance.

This can be achieved through detailed process below;

Process of Developing a Teacher- Learner Participatory Conducive Approach for Learning and Teaching of Physical Education using Social /Emancipation Action Principles

\section{GENERATING FORMATIVE INORMATION (PHASE ONE)}

\{Pre Requisite Standardasised information based on teacher- learner Perceptions\}

- The reason is because there is no conducive approach for learning of physical education among teachers and learners in Zambia.

- The Pre Requisite standardized questions from teacher- learner perceptions are;

a. Identification of gaps in the Programs and Policies of teaching and learning of physical education.

b. Contributors of challenges in the teaching and learning of physical education.

c. Classification of challenges in the teaching and learning of physical education.

\section{DEVELOPING THEPARTICIPATORY CONDUCIVE APPROACH (PHASE TWO)}

- Selection criteria for participants and their areas of origin to engage in the group Emancipation

a. All the learner and teacher's victims of challenges of learning and teaching of the subject will be purposively selected to form part of the group.

b. They must have been learning and teaching of the subject for not less than three years.

c. Further some specific areas will be considered in terms of location

- Eliciting of conducive ways of learning and teaching of physical education from the emancipation groups (Corroboration)

a. An Action Agenda for Change in form of a predetermined question by the researcher is used to elicit the prevention ways from the group under the guidance of the researcher who also takes down the notes.

- Analysis and Interpretation of input from the participants

a. Upon the completion of the collection of the conducive ways of teaching and learning of the subject from the group the researcher proceeds to give meaning to the input.

- Validation and Consensus building with the group

a. After having given meaning to the conducive ways of the group the researcher returns back the information back to the participants for the final adoption.

b. The participatory conducive approach is given a formal identification name.

Adapted from Egaden (2012). 


\section{ACKNOWLEDGEMENT}

I wish to thank my supervisors Prof. C Chishimba for the guidance in this research thesis.I further thank Dr Chipande and all the Lecturers in the Department of Physical Education Studies for their advice. I also thank the District education board secretary of Monze and the rest of Ministry of education at different levels for their support and blessings.

\section{REFERENCES}

[1] Aquene, D. (2012). Challenges in the teaching and learning of physical education by learners in selected secondary schools of Kumasi, University of Ghana publishers, Kumasi.

[2] Bless, C and Achola, P. (2001). Fundamentals of Social Research Methods, Pauline Publishers, Nairobi.

[3] Bucher, C.A. (1979). Administration of Physical Education and athletic program: $7^{\text {th }}$ Edition. St Louis: Edmund.

[4] Creswell, J.W. (2007). Qualitative Inquiry and Research Designs: Choosing Among Five Approaches, $2^{\text {nd }}$ ed. Sage Publishers, London.

[5] Creswell, J.W. (2009). Research design: Qualitative, Quantities and Mixed methods Approaches, Sage Publishers, New Delhi.

[6] Cohen, A. (2001). Review of Literature: Responses to "Empirical and Hermeneutic Approaches to Phenomological research in Psychology, a Comparison" Gestalt, 5 (2) retrieved from http:www.ggej.org/5-2/reviewlit.html.

[7] Egaden, C.L. (2012). Participatory Action/Toolkit Procedure using Future Search Research: A Modern Thought for Doctoral and Post Doctoral Students, Sage Publications, London.

[8] Giorgi, A e’ tal. (1985), Phenomenology and Psychological Research Duquesne University Press, Pittsburg.

[9] Faber, L E'tal (2007), Strategies for physical activity promotion beyond the physical education classroom. Journal of physical education, recreation and dance, 78 (9), 27-31.

[10] Hart, C. (2013). Doing a Literature Review: Release the Social Science imagination, Sage Publications, London.

[11] Holloway I. and Wheeler S. (1996). Qualitative Research for Nurses, Hartinolis Ltd, London.

[12] Kafoe, R. (2011). Challenges in the teaching and learning of physical education by the teachers

[13] In some selected primary schools of Accra, University of Ghana publishers, Accra.

[14] Kapembwa, G. (2015). Perceptions of Physical Education among pupils in selected schools of Lusaka district, University of Zambia publishers, lusaka, Zambia.

[15] Kombo, D. K. and tromp, L. A. (2006). Proposal and Thesis Writing: An Introduction, Pauline Publication Africa, Nairobi.

[16] Krueger, R. A. (1988). Focus Groups and Interviews: A practical Guide for Applied Research Methods. Sage Publishers, London.

[17] Leedy, A. and Omorod, J. F. (2005). Practical Research Planning and Design. Merrill Prentice Publishers, New Jersey.

[18] Loopstra, O. E'tal (1997). Physical education from a European point of view. European union paper EU-1478

[19] Minichioelo, V. Aroni, R, Time well, E. and Alexander, L. (1990). Qualitative data analysis in depth Interviewing: Qualitative Approach, Sage Publishers, Thousand Oaks.

[20] Morgan, P.J. and Hansen. (2014). Classroom teacher perceptions of the impact of barriers to teaching physical education on the quality of physical education programs. Research quarterly for exercise and sport, 79(4),506-516

[21] Musangenya, E. E’tal (2000). Historical perspectives in physical education and sport. Harare, Zimbabwe Open University.

[22] Muswazi, T.M. (2013). Challenges of Physical Education In selected secondary schools of Harare, Harare.

[23] Mwashingwele P. C. (2015). Factors affecting the implementation of physical education in primary school curriculum: A case of selected primary schools in Chibombo District, University of Zambia publishers, lusaka, Zambia.

[24] Nhamo. E and Muswazi, T.M. (2013). The contribution of sport and physical activity towards achieving of the community health objectives. IOSR Journal of sports and physical education (IOSR-JSPE) volume 1, issue (sep-oct.2013) pp14-19

[25] Nhamo. E and Muswazi, T.M. (2014). Physical Education perceptions from selected schools on the teaching and learning of physical education in Harare, Dissertation, University of Harare publishers, Harare. 
[26] Patton, M.Q. (2002). Qualitative Research and Evaluation Methods. Thousand oaks, London.

[27] Punch, K. F. (2012). Introduction to Social Research: Quantitative and Qualitative Approaches, Sage Publications, London.

[28] Shimishi, G. (2015). The role of Physical Education in promoting learner academic performance: A case study of Kombanya primary school of mansa district, luapula province, Zambia. University of Zambia publishers, lusaka, Zambia.

[29] Sitima, M. (2015). Constraints of implementing of physical education and sport as a compulsory subject among selected primary schools in Mansa district of Zambia. University of Zambia publishers, lusaka, Zambia

[30] Storthart, R.A. (1997). The rise and demise of a physical education advisory service: The New Zealand experience. F.I.E.P. Bulletin, 67 (3),23-25.

[31] UNESCO. (1978). International charter of physical education and sport, UN publishers, New York.

[32] Wilcox, R. (1998). Shared skepticism and domestic doubts: Globalisation, today and the challenges of physical education. Sports journal issue 21998

[33] Williams, P. (1993). Implementing a new integrated curriculum in Australia: The views of Head teachers, physical education. Physical Education review, 16 (1), 31-40 
AUTHORS' BIOGRAPHY

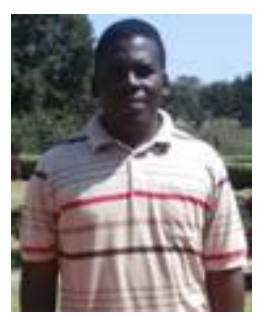

Thomas Mwale, a Master of Education in Physical Education, at the University of Zambia. He is a Senior Lecturer and Examiner of Physical Education at David Livingstone College of Education. He is the Principal and Main Researcher in this Inquiry.

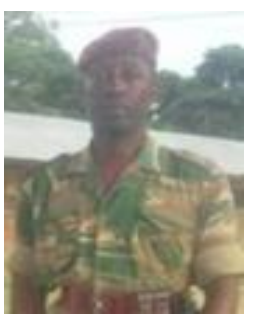

John Mwitumwa Matakala, a Doctor of Philosophy Research Fellow in Gender Studies, at the University of Zambia. He is an Assistant Researcher in this Inquiry. $\mathrm{He}$ is also Special Force Soldier in the Commando Unit.

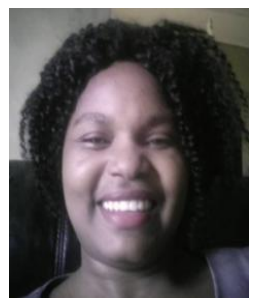

Chimfwembe Mwenya-Mwale, a master of Art with education religious and development studies at the University of Zambia. She is a high school teacher, grade twelve examiner and marker. She has a seven year teaching experience. She is an Assistant Researcher in this Inquiry.

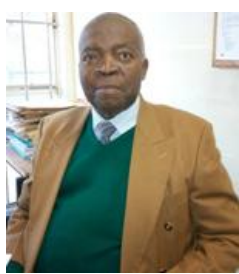

Prof. Chanda. P. Chishimba, The professor of teacher education in the department of primary education at the University of Zambia. He is Holds a doctor of education in curriculum and teaching in teacher education from Colombia. He also holds a Master and bachelor of primary education from the University of Zambia. He is a Publisher of the Book Entitled 'Perspectives for Teachers of English as a Second Language Published by the University of Zambia. He is the Principal and Main Supervisor in this Inquiry. Senior lecturer/researcher - department of teacher education.

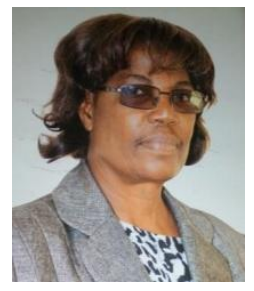

Prof. Mubiana Macwan'gi, the Professor of Public Health and Behavioural Scientist. Was the Institute of Economic and Social Research Director - 2010 To 2016 at the University of Zambia. She is a Research and Innovation Advisor in this Inquiry. Senior Lecturer/Researcher - Department of Gender Studies.

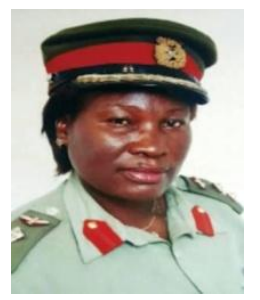

Dr. Annie Namakando -Phiri (Col), the Doctor of Public Healthy /Epidemiology/ Gender. She is also a Senior Retired army officer. Was a Head of Department - 2013 To 2016 at the University of Zambia. She is a Research and Phenomenological Advisor in this Inquiry. Senior Lecturer/Researcher - Department of Gender Studies.

Citation: Thomas Mwale, et al. "Experiences of Teachers and Learners in the Teaching and Learning of Physical Education in Selected Schools in Monze, Zambia."International Journal of Humanities Social Sciences and Education (IJHSSE), vol 5, no. 8, 2018, pp. 1-11. doi: http://dx.doi.org/10.20431/23490381.0508001 .

Copyright: () 2018 Authors. This is an open-access article distributed under the terms of the Creative Commons Attribution License, which permits unrestricted use, distribution, and reproduction in any medium, provided the original author and source are credited. 